\title{
In Vitro Propagation of Eriostemon myoporoides and Eriostemon 'Stardust'
}

\author{
James R. Ault \\ Department of Horticulture, Longwood Gardens, P. O. Box 501, Kennett \\ Square, PA 19348
}

Additional index words. wax flower, micropropagation, tissue culture

\begin{abstract}
Optimal axillary shoot proliferation was obtained from stem explants of a clone of Eriostemon myoporoides DC. on Murashige and Skoog (MS) basal medium containing $0.1 \mathrm{mg} \mathrm{BA} / \mathrm{liter}$, and of Eriostemon 'Stardust' on MS medium containing $0.5 \mathrm{mg} \mathrm{BA} / \mathrm{liter}$. Overall average number of shoots and shoot lengths for all treatments was greater for $E$. 'Stardust' (22.4 shoots and 12.1-mm shoot length) than for $E$. myoporoides (4.5 shoots and 8.3-mm shoot length). Maximum percent rooting of $E$. myoporoides $(42 \%)$ and $E$. 'Stardust' $(95 \%)$ was obtained on MS medium supplemented with $1.0 \mathrm{mg}$ K-IBA/liter for $E$. myoporoides and $0.1 \mathrm{mg}$ NAA/liter for $E$. 'Stardust'. Overall average percent rooting and root lengths were greater for $E$. 'Stardust' $(42 \%$ rooting and 11.0-mm root length) than for $E$. myoporoides (27\% rooting and $2.3-\mathrm{mm}$ root length). For $E$. 'Stardust', reducing sucrose in the rooting medium from 50 to 25 g.liter ${ }^{-1}$ significantly decreased overall average percent rooting to 1670 and root length to $6.8 \mathrm{~mm}$. Plantlets of both clones were acclimatized in the greenhouse and transferred successfully to soil, although survival was <7070. Chemical names used: $N$-(phenylmethyl) -l $H$-purine-6-amine (BA); potassiumI $H$-indole-3-butyric acid (K-IBA); l-naphthaleneacetic acid (NAA).
\end{abstract}

Species and hybrids of Eriostemon Smith, an endemic genus of Australia, are evergreen shrubs grown for their profusion of long-lasting white or pink flowers and for the fragrant foliage. In the United States, these plants have potential as hardy shrubs in near frost-free zones, as greenhouse crops, and as cut flowers.

Cultivars and superior, unnamed clones of Eriostemon must be propagated vegetatively to maintain genetic integrity. However, stem cuttings of Eriostemon can be slow to root or root poorly (Elliot and Jones, 1984; Nixon, 1980), and ease of stem-cutting propagation can be clone-specific (Ellyard, 1984). Plummer and de Fossard (1981) successfully tissueculture-propagated E. australasius Pers. Reported herein is a successful micropropagation protocol for a single unnamed, selected clone of E. myoporoides and for E. 'Stardust', a cultivar developed in Australia from the cross E. myoporoides DC. $\times$ E. verrucosus A. Rich. (Elliot and Jones, 1984).

\section{Materials and Methods}

Actively growing shoots $\approx 15 \mathrm{~cm}$ long were harvested from greenhouse-grown plants. The leaves were removed and shoots were rinsed in running tap water for $30 \mathrm{~min}$. Shoots were surface-sterilized by dipping in $70 \%$ ethanol, followed by a 12 -min soak in $1.0 \%$ sodium hypochlorite plus $1.0 \%$ Tween 20 (Polysciences, Warrington, $\mathrm{Pa}$.), then rinsed twice (5 min each time) in sterile distilled water. Primary explants, consisting of single-node

Received for publication 28 June 1993. Accepted for publication 12 Jan. 1994. The cost of publishing this paper was defrayed in part by the payment of page charges, Under postal regulations, this paper therefore must be hereby marked advertisement solely to indicate this fact. stem segments $\approx 2.0 \mathrm{~cm}$ long, were aseptically excised and inserted (one per tube, proximal portion down) into $25 \times 150$-mm glass culture tubes containing $10 \mathrm{ml}$ Murashige and Skoog (MS) (Murashige and Skoog, 1962) basal medium supplemented with $50 \mathrm{~g}$ sucrose/liter, 7.0g agar/liter (Sigma Chemical Co., St. Louis), and selected concentrations of BA. Media $\mathrm{pH}$ were adjusted to 5.7 with $1 \mathrm{~N} \mathrm{NaOH}$ before adding agar, then autoclave for $15 \mathrm{~min}$ at $121 \mathrm{C}$. These and all other culture tubes were sealed with polypropylene test tube caps and parafilm, placed vertically in 40-tube racks in an incubator (model 8 18; Precision Scientific, Chicago), and maintained at $25 \mathrm{C}$ with a $16-\mathrm{h}$ photoperiod provided by two vertical interior door-mounted 40-W Verilux broad-spectrum fluorescent lamps (Verilux, Greenwich, Corm.). The culture tubes were positioned 12 to $42 \mathrm{~cm}$ from the lamps. liferation studies consisted of 20 explants per treatment for each clone placed on basal media supplemented with $0.0,1.0,2.5$, or $5.0 \mathrm{mg} \mathrm{BA} /$
Preliminary shoot establishment and pro-

liter. Primary explants on medium without BA typically produced one axillary shoot per node, whereas multiple shoot proliferation occurred on medium supplemented with 1.0 or $2.5 \mathrm{mg}$ BA/liter. Explants on medium supplemented with $5.0 \mathrm{mg}$ BAiliter turned brown with no growth or with only slight axillary shoot proliferation (data-not presented). Subsequently, all shoots produced with BA at $0.0,1.0$, or 2.5 $\mathrm{mg} \cdot$ liter $^{-1}$, within each clone, were randomized and recultured for one to three subculture periods, each 6 to 12 weeks in duration, on basal medium supplemented with $0.1 \mathrm{mg} \mathrm{BA} /$ liter before further shoot proliferation and rooting studies. For shoot proliferation, 20 explants per clone per treatment were cultured on basal medium supplemented with 0.0,0.1, $0.5,1.0,2.0$, or $3.0 \mathrm{mg} \mathrm{BA} /$ liter. Each explant consisted of a single, unbranched, decapitated four-node shoot. Cultures were harvested after 8 weeks, and the number of shoots per explant and shoot lengths were recorded. For rooting studies, 20 to 30 shoots per clone per treatment were placed on basal medium supplemented with -either $0.1,0.5,1.0$, or $2.0 \mathrm{mg}$ NAA/liter; $0.1,0.5,1.0$, or $2.0 \mathrm{mg} \mathrm{K}-\mathrm{IBA} /$ liter; or the combination of $0.05,0.25,0.5$, or $1.0 \mathrm{mg}$ each of NAA + K-IBA/liter. Explants consisted of unbranched shoots $\approx 3$ to $4 \mathrm{~cm}$ long that were oriented vertically and inserted one shoot per tube, the distal $5 \mathrm{~mm}$ of each shoot being inserted into the medium.

For $E$. 'Stardust', an additional rooting study was conducted using the identical auxin treatments, but the basal medium contained 25 g sucrose/liter. Shoots were maintained in an incubator as described previously. All shoots were harvested after 8 to 10 weeks, and percent rooting, number of roots per rooted shoot, and root lengths were recorded. Shoots were recorded as rooted if one or more roots $\geq 1.0$ $\mathrm{mm}$ in length was detected on the portion of shoot inserted into the medium. Rooted shoots of both clones were removed from culture, rinsed free of medium, then planted in 50-cell plug trays, each cell containing $\approx 90 \mathrm{~cm}^{3} \mathrm{me}-$ dium of a 2 perlite: 1 peat ( $\mathrm{v} / \mathrm{v})$ medium. Trays were covered with clear plastic domes, then placed under 50\% shadecloth in a greenhouse with a maximum $24 \mathrm{C}$ day/minimum $18 \mathrm{C}$ night and with a 10.5-h photoperiod. The plastic domes were ventilated after 2 weeks and completely removed after 3 weeks.

Table 1. Effects of BA on shoot proliferation of Eriostemon myoporoides and Eriostemon 'Stardust'.

\begin{tabular}{|c|c|c|c|c|}
\hline \multirow[b]{2}{*}{$\begin{array}{l}\text { BA } \\
\left(\mathrm{mg} \cdot \text { liter }^{-1}\right)\end{array}$} & \multicolumn{2}{|c|}{ E. myoporoides } & \multicolumn{2}{|c|}{ E. Stardust } \\
\hline & $\begin{array}{c}\text { No. shoots/ } \\
\text { explant }\end{array}$ & $\begin{array}{c}\text { Shoot } \\
\text { length } \\
(\mathrm{mm})\end{array}$ & $\begin{array}{l}\text { No. shoots/ } \\
\text { explant }\end{array}$ & $\begin{array}{l}\text { Shoot } \\
\text { length } \\
\text { (mm) }\end{array}$ \\
\hline 0.0 & $1.6 \pm 0.3^{2}$ & $16.1 \pm 1.6$ & $1.3 \pm 0.3$ & $14.6 \pm 1.1$ \\
\hline 0.1 & $6.3 \pm 0.8$ & $14.2 \pm 0.8$ & $18.7 \pm 1.6$ & $18.4 \pm 0.7$ \\
\hline 0.5 & $4.0 \pm 0.2$ & $4.1 \pm 0.4$ & $27.8 \pm 2.2$ & $15.7 \pm 1.3$ \\
\hline 1.0 & $4.9 \pm 0.4$ & $7.9 \pm 0.7$ & $26.1 \pm 2.2$ & $12.1 \pm 0.3$ \\
\hline 2.0 & $4.5 \pm 0.4$ & $5.5 \pm 0.6$ & $27.4 \pm 1.4$ & $9.1 \pm 0.2$ \\
\hline 3.0 & $5.6 \pm 0.6$ & $4.6 \pm 0.5$ & $28.2 \pm 2.3$ & $7.2 \pm 0.2$ \\
\hline Grand mean & $4.5 \pm 0.3$ & $8.3 \pm 0.3$ & $22.4 \pm 1.1$ & $12.1 \pm 0.3$ \\
\hline \multicolumn{5}{|l|}{ Regression } \\
\hline Linear & $*$ & $* * *$ & $* * *$ & $* * *$ \\
\hline Quadratic & NS & $* * *$ & $* * *$ & $* * *$ \\
\hline
\end{tabular}

${ }^{2}$ Mean \pm 1 SE.

${ }^{\mathrm{NS},}{ }^{*}{ }^{* * *}$ Nonsignificant or significant at $P \leq 0.05$ or 0.001 , respectively. 

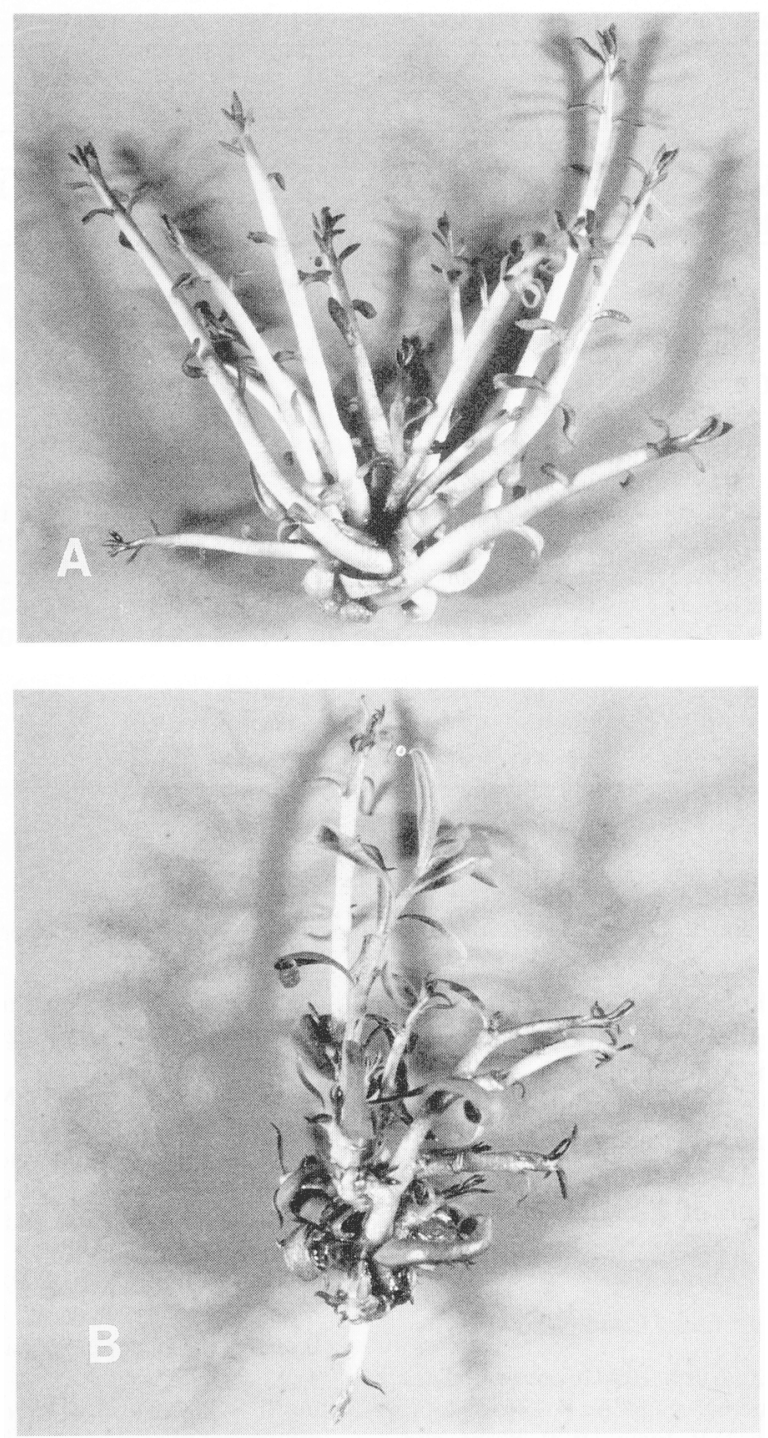

Fig. 1. Axillary shoot proliferation after 8 weeks of culture for (A) Eriostemon myoporoides on medium supplementedwith1.0mgBA/literand (B) Eriostemon 'Stardust' on medium supplemented with 0.1 $\mathrm{mgBA} /$ liter.

All proportional data were analyzed using Chi-square tests. All other data were analyzed using polynomial regression or analysis of variance (ANOVA) using CoStat statistical software (CoHort Software, Berkeley, Calif.).

\section{Results and Discussion}

There were significant differences in the number of shoots formed per explant and in shoot length for E. myoporoides and E. 'Stardust' (Table 1, Fig. 1). Shoot counts were higher for all BA treatments, indicating BA overcame any effects of apical dominance within the explants. For both clones, increasing BA concentrations reduced shoot elongation. This response has been observed in other micropropagation protocols ( $\mathrm{Hu}$ and Wang, 1983). Eriostemon 'Stardust' appears to be more amenable to tissue culture proliferation, as both the overall mean number of shoots per explant and shoot lengths for $E$. 'Stardust' exceeded those for E. myoporoides (Table 1). For multiplication purposes, $0.1 \mathrm{mg}$ BA/liter appears optimal for E. myoporoides and ei- ther 0.5 or $1.0 \mathrm{mg} \mathrm{BA} /$ liter for $E$. 'Stardust'.

Percent rooting, number of roots per rooted shoot, and root lengths of both clones were significantly different for individual auxin treatments. The number of roots per rooted shoot and root lengths of E. myoporoides and percent rooting and number of roots per rooted shoot of $E$. 'Stardust' were significantly affected by the type of auxin treatment (NAA, K-IBA, or NAA + K-IBA) (Table 2, Fig. 2). The variable responses within each clone make it difficult to recommend any single auxin type or concentration as optimal for all three rooting responses, i.e., percent rooting, root length, and root count. Maximum percent rooting of $E$. myoporoides(42\%) and E. 'Stardust' (95\%) was obtained on media with $1.0 \mathrm{mg} \mathrm{K}-\mathrm{IBA} /$ liter and $0.1 \mathrm{mg}$ NAA/liter, respectively. Percent rooting and root length of $E$. 'Stardust' increased significantly, but root count was not significantly changed by the difference in sucrose concentration in the rooting medium (25 vs. $50 \mathrm{~g}$.liter ${ }^{-1}$ ) (Table 2). Increased percent rooting with increased sucrose concentration has been reported for other tissue culture pro-
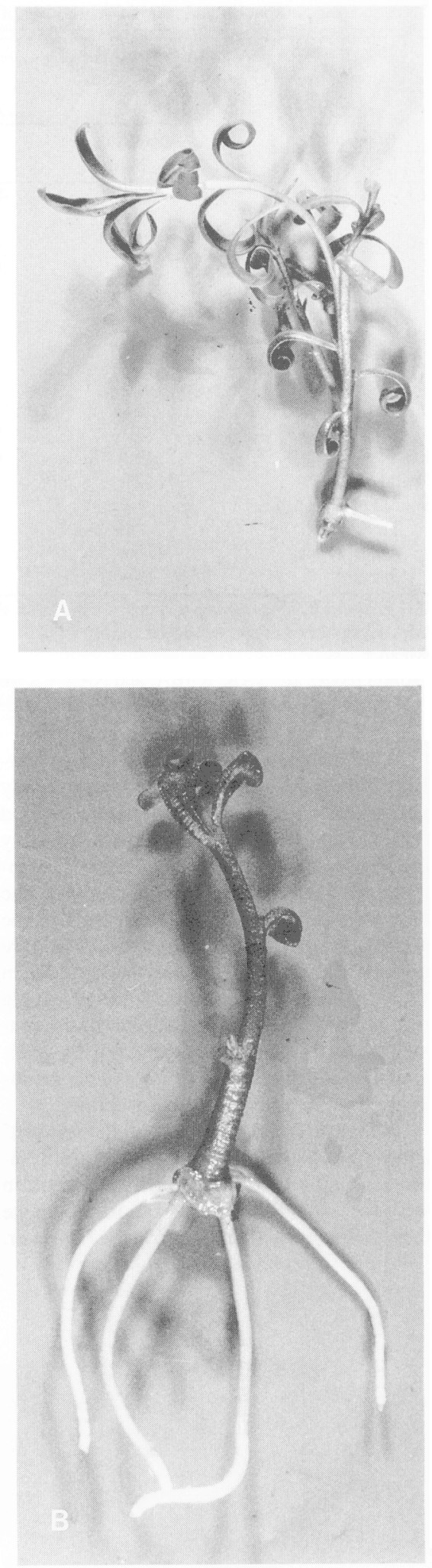

Fig. 2. Rooting after 8 weeks of culture for (A) Eriostemon myoporoides on medium supplemented with $1.0 \mathrm{mg} \mathrm{K}-\mathrm{IBA} / \mathrm{liter}$ and (B) Eriostemon 'Stardust' on medium supplemented with $2.0 \mathrm{mg} \mathrm{K}$-IBA/liter.

tocols (Chu and Kurtz, 1990). As with shoot proliferation, the overall mean rooting percentages and root lengths on media with $50 \mathrm{~g}$ sucrose/liter for $E$. 'Stardust' exceeded those for E. myoporoides (Table 2). 


\begin{tabular}{|c|c|c|c|c|c|c|c|c|c|c|}
\hline & & & & & \multicolumn{6}{|c|}{ E. Stardust } \\
\hline & & & & & \multicolumn{6}{|c|}{ Sucrose (g.liter ${ }^{-1}$ ) } \\
\hline \multirow{2}{*}{\multicolumn{2}{|c|}{$\begin{array}{c}\text { Auxin } \\
\left(\mathrm{mg} \cdot \text { liter }^{-1}\right)\end{array}$}} & \multicolumn{3}{|c|}{ E. myoporoides ${ }^{\mathrm{z}}$} & 25 & 50 & 25 & 50 & 25 & 50 \\
\hline & & \multirow{2}{*}{$\begin{array}{c}\text { Rooting } \\
(\%)\end{array}$} & \multirow{2}{*}{$\begin{array}{l}\text { Roots' } \\
\text { shoot }^{y}\end{array}$} & \multirow{2}{*}{$\begin{array}{c}\text { Root } \\
\text { length }(\mathrm{mm})\end{array}$} & \multirow{2}{*}{\multicolumn{2}{|c|}{$\begin{array}{c}\text { Rooting } \\
(\%)\end{array}$}} & \multirow{2}{*}{\multicolumn{2}{|c|}{ Roots/shoot ${ }^{y}$}} & \multirow{2}{*}{\multicolumn{2}{|c|}{$\begin{array}{l}\text { Root length } \\
\text { (mm) }\end{array}$}} \\
\hline NAA & K-IBA & & & & & & & & & \\
\hline 0.1 & 0.0 & 39 & $4.4 \pm 0.8^{x}$ & $1.8 \pm 0.2$ & 30 & 95 & $1.5 \pm \overline{0.3}$ & $3.5 \pm 0.4$ & $3.4 \pm 1.1$ & $8.3 \pm 0.8$ \\
\hline 0.5 & 0.0 & 28 & $2.8 \pm 1.1$ & $1.6 \pm 0.2$ & 20 & 38 & $6.5 \pm 3.9$ & $3.9 \pm[.4$ & $1.9 \pm 0.2$ & $9.4 \pm 1.6$ \\
\hline 1.0 & 0.0 & 39 & $4.8 \pm 0.7$ & $1.7 \pm 0.1$ & 0 & 37 & 0.0 & $3.5 \pm 1.1$ & 0.0 & $14.6 \pm 1.7$ \\
\hline 2.0 & 0.0 & 33 & $6.5 \pm 2.1$ & $2.9 \pm 0.4$ & 15 & 24 & $2.7 \pm 0.3$ & $1.4 \pm 0.4$ & $13.5 \pm 4.2$ & $7.3 \pm 3.7$ \\
\hline 0.0 & 0.1 & 0 & 0.0 & 0.0 & 0 & 23 & 0.0 & $1.4 \pm 0.2$ & 0.0 & $5.3 \pm 2.5$ \\
\hline 0.0 & 0.5 & 11 & $1.0 \pm 0.0$ & $5.5 \pm 3.5$ & 5 & 28 & $1.0 \pm 0.0$ & $1.3 \pm 0.2$ & $36.0 \pm 0.0$ & $5.5 \pm 2.1$ \\
\hline 0.0 & 1.0 & 42 & $1.3 \pm 0.2$ & $2.7 \pm 0.8$ & 10 & 24 & $1.0 \pm 0.0$ & $1.9 \pm 0.4$ & $18.0 \pm 17.0$ & $13.8 \pm 3.1$ \\
\hline 0.0 & 2.0 & 28 & $1.0 \pm 0.0$ & $2.2 \pm 0.6$ & 0 & 38 & 0.0 & $1.8 \pm 0.5$ & 0.0 & $9.9 \pm 2.0$ \\
\hline 0.05 & 0.05 & 35 & $1.5 \pm 0.5$ & $1.7 \pm 0.7$ & 25 & 58 & $1.4 \pm 0.2$ & $2.1 \pm 0.3$ & $4.6 \pm 1.3$ & $4.5 \pm 0.7$ \\
\hline 0.25 & 0.25 & 25 & $4.0 \pm 2.0$ & $1.4 \pm 0.2$ & 45 & 81 & $5.6 \pm 1.4$ & $5.4 \pm 0.7$ & $7.5 \pm 0.9$ & $12.5 \pm 1.3$ \\
\hline 0.5 & 0.5 & 10 & $9.0 \pm 0.0$ & $2.6 \pm 0.4$ & 20 & 38 & $2.5 \pm 1.0$ & $4.6 \pm 1.2$ & $9.8 \pm 2.3$ & $14.4 \pm 2.2$ \\
\hline 1.0 & 1.0 & 30 & $6.2 \pm 1.0$ & $3.0 \pm 0.6$ & 20 & 46 & $1.8 \pm 0.5$ & $2.2 \pm 0.9$ & $6.9 \pm 2.1$ & $17.0 \pm 4.4$ \\
\hline Grand & & 27 & $3.7 \pm 0.4$ & $2.3 \pm 0.2$ & 16 & 42 & $3.2 \pm 0.3$ & $3.0 \pm 0.2$ & $6.8 \pm 0.7$ & $11.0 \pm 0.6$ \\
\hline \multicolumn{11}{|c|}{ Source of variation } \\
\hline \multicolumn{2}{|c|}{ Treatment } & $*$ & $* *$ & $* *$ & \multicolumn{2}{|c|}{$* *$} & \multicolumn{2}{|c|}{$* *$} & \multicolumn{2}{|c|}{$--* *$} \\
\hline \multicolumn{2}{|c|}{ Auxin block ${ }^{w}$} & NS & $* *$ & $*$ & \multicolumn{2}{|c|}{$* *$} & \multicolumn{2}{|c|}{$* *$} & \multicolumn{2}{|c|}{ NS } \\
\hline \multicolumn{2}{|c|}{ Sucrose } & -- & --- & -- & \multicolumn{2}{|c|}{$* *$} & \multicolumn{2}{|c|}{ NS } & \multicolumn{2}{|c|}{$* *$} \\
\hline
\end{tabular}

${ }^{\mathrm{z}}$ All $E$. myoporoides rooting responses were from shoots on medium with $50 \mathrm{~g}$ sucrose/liter.

${ }^{y}$ Mean number of roots per rooted shoot.

${ }^{x}$ Mean $\pm 1 \mathrm{SE}$.

${ }^{\text {w} A u x i n ~ b l o c k s ~ a r e ~ N A A, ~ K-I B A, ~ a n d ~ N A A ~+~ K-I B A ~ t r e a t m e n t s, ~ r e s p e c t i v e l y . ~}$

${ }_{N S}^{*},{ }^{* *}$ Nonsignificant or significant at $P \leq 0.05$ or 0.01 , respectively, according to Chi-square test for percent rooting and to ANOVA for other data.

Acclimatization and survival of the plantlets resulting from tissue culture was relatively poor- $49 \%$ (29 of 42$)$ for E. myoporoides and $54 \%$ (54 of 100) for E. 'Stardust'-possibly because of the relatively poor root development on many of the shoots. Many of the nonsurviving plantlets had not rooted into the growing medium in the greenhouse. For more optimal survival, enhancing root growth in vitro before acclimatization and improving root growth during acclimatization in the greenhouse may be necessary. One year after acclimatization, plants of both clones in the greenhouse appeared normal in morphology.

Eriostemon myoporoides and E. 'Stardust' appear amenable to tissue culture proliferation. It may be possible to maintain stock in vitro for extended periods, and to propagate these plants on a year-round basis. However, in vitro rooting percentages are not superior to rooting percentages of conventional stem-cutting propagation. Additional research is warranted to improve in vitro rooting and greenhouse acclimatization before micropropagation can be considered an economic alternative to clonal propagation of Eriostemon by stem cuttings.

\section{Literature Cited}

Chu, I.Y.E. and S.L. Kurtz. 1990. Commercialization of plant micropropagation, p. 126-164. In: P.V. Ammirato, D.R. Evans, W.R. Sharp, and Y.P.S. Bajaj (eds.). Handbook of plant cell culture:Ornamentalspecies, vol. 5. McGraw-Hill, New York.

Elliot, W.R. and D.L. Jones. 1984. Encyclopedia of Australianplantssuitableforcultivation. vol. 3 . LothianPublishing,Melbourne, Australia.
Ellyard, R. 1984. Propagation of Eriostemon australasius Pers.bycuttings. Plant Propagator 30(1):10-13.

Hu, C.Y. and P.J. Yang, 1983. Meristem, shoot tip and bud culture, p. 177-227. In: D.A. Evans, W.R. Sharp, P.V. Ammirato, and Y. Yamada (eds.). Handbook of plant cell culture: Techniques for propagation and breeding. vol. 1 . Macmillan, New York.

Murashige, T. and F. Skoog. 1962. A revised medium for rapid growth and bioassays with tobacco tissue cultures. Physiol. Plant. 15:473479.

Nixon, P. 1980. Eriostemon australasius. An improvementof seed propagation, Austral. Plants 10(84):368-369.

Plummer, J.A. and R.A. de Fossard. 1981. The influenceofplant hormones and growth factors on growth of Eriostemon australasius Pers. in tissue culture. Proc. Intl. Plant Prop. Soc. 31:295303. 